\title{
Evaluation of polycyclic aromatic hydrocarbons (PAHs) pollution in Büyük Menderes River
}

\section{Büyük Menderes Nehri'nde polisiklik aromatik hidrokarbon (PAH) kirliliğinin değerlendirilmesi}

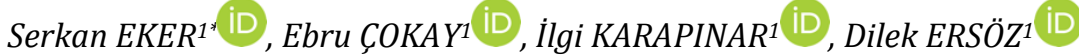 \\ 1Department of Environmental Engineering, Dokuz Eylul University, Izmir, Turkey. \\ serkan.eker@deu.edu.tr; ebru.cokay@deu.edu.tr; ilgi.karapinar@deu.edu.tr; ersz.dilek@gmail.com
}

\section{Abstract}

Polycyclic aromatic hydrocarbons (PAHs) tend to accumulate in the environment, causing environmental pollution through which they significantly affect the biological equilibrium in nature. Due to their adverse effect on nature, aquatic life and human, PAHs are considered as one of the significant pollutants that should be monitored in surface water bodies. Therefore, they have been listed in the national specific pollutant list of Republic of Turkey, Ministry of Agriculture and Forestry and in the priority substances list specified in EU Water Frame Directive (WFD) of 2000/60/EC and 2013/39/EU. Anthracene, Benzo[a]pyrene, Benzo[b]fluoranthene, Benzo[ghi]perylene, Benzo[k]fluoranthene, Fluoranthene, Indeno $[1,2,3-c d]$ pyrene, Naphthalene are the PAHs in the priority substances list of WFD. Additionally, 1-Methylnaphthalene, Acenaphthene, Acenaphthylene, Chrysene, Fluorene, Perylene, Phenanthrene, Pyrene are other PAHs with environmental quality standards specified in the national list of the Ministry. The mentioned PAHs were monitored for 12 months in 15 lakes, 2 transition water, 4 coastal and 26 river water stations in Büyük Menderes River Basin. The results were evaluated for the detected PAHs in the river basin with regard to Maximum Allowable Concentration Environmental Quality Standards (MAC-EQS) and the Annual Average Concentration Environmental Quality Standards (AA-EQS) given either in Water Framework Directive or in National Regulation of the Ministry. As a result of the evaluation, benzo[k]fluoranthene, benzo[ghi]perylene, pyrene and fluoranthene substances were found to be important substances to be monitored throughout the basin.

Keywords: Polycyclic aromatic hydrocarbons, PAHs, Water framework directive, Büyük Menderes River

\section{Introduction}

PAHs are a group of compounds consisting of two or more fused aromatic rings and they can form by anthropogenic activities or could naturally occur. It is possible to find PAHs in almost every environment such as water, soil and air [1].

They are often used in pharmaceuticals, agricultural products and some chemical industries such as dyes and plastic. PAHs are emitted to the atmosphere through incomplete combustion of fossil fuels [2] and then they pass into water and soil with rainfall or dust particles. The accumulation of PAH on the earth surface substantially affects the biological equilibrium such a way as bioaccumulation in the living organisms especially in the aquatic environment and then transmission to the human body through the food chain. Although the health effect of each $\mathrm{PAH}$ varies depending on its hydrophobic and hydrophilic nature, they are defined as dangerous chemical substances that

\section{Öz}

Polisiklik aromatik hidrokarbonlar (PAH'lar) çevrede birikme eğilimi göstermesi nedeniyle çevre kirliliğine neden olurlar ve biyolojik dengeyi önemli ölçüde etkilerler. Doğa, sucul yașam ve insan üzerindeki olumsuz etkilerinden dolayı, PAH'lar, yüzey suyu kütlelerinde izlenmesi gereken önemli kirleticilerden biri olarak kabul edilir. Bu nedenle, Türkiye Cumhuriyeti, Tarım ve Orman Bakanlığı'nın ulusal spesifik kirletici listesinde ve 2000/60 / EC ve 2013/39 / EU sayıl AB Su Cerçeve Direktifi'nde (SÇD) belirtilen öncelikli maddeler listesinde listelenmiștir. Antrasen, Benzo [a] piren, Benzo [b] floranten, Benzo [ghi] perilen, Benzo [k] floranten, Floranten, Indeno [1,2,3-cd] piren, Naftalin, SCD öncelikli maddeler listesinde yer alan PAH'lardır. Ayrıca, 1 Metilnaftalin, Asenaften, Asenaftilen, Krisen, Floren, Perilen, Fenantren, Piren Bakanlığın ulusal listesinde belirtilen çevresel kalite standartlarına sahip diğer PAH'lardır. Söz konusu PAH'lar Büyük Menderes Havzası'nda 15 göl, 2 geçiş suyu, 4 kıyı ve 26 nehir suyu istasyonunda 12 ay boyunca izlenmiştir. Sonuçlar, nehir havzasinda tespit edilen PAH'lar için İzin Verilen Maksimum Konsantrasyon Cevre Kalite Standartları (MAC-EQS) ve Su Çerçeve Direktifi veya Ulusal Yönetmelikte verilen Ylllk Ortalama Konsantrasyon Cevre Kalite Standartları (AA-EQS) açısından değerlendirilmiştir. Değerlendirmeler sonucunda, Benzo [k] floranten, Benzo [ghi] perilen ve Floranten maddelerinin havza boyunca izlenmesi gereken önemli maddeler olduğu görülmüştür.

Anahtar kelimeler: Polisiklik aromatik hidrokarbonlar, PAH, Su cerçeve direktifi, Büyük Menderes Nehri

should be monitored due to the carcinogenic effects of some PAHs on humans [1].

In this context, EU declared that PAHs as one of the most significant pollutants to be controlled and monitored in water bodies based on Water Framework Directive (WFD). WFD of the European Union (EU) covers the principles of River Basin Management Plans and provides a program and timetable for EU member states to constitute management plans. There are number of directives to protect aquatic biodiversity, drinking water resources and the other directives for the protected areas. Water quality for surface waters is evaluated based on ecological, chemical and hydromorphological status of the water. The chemical status of the water is evaluated by considering the existence of priority and the specific pollutants. The water framework directive declared 45 pollutants priority substances which include PAHs, pesticides, halogenated hydrocarbons, heavy metals, alkyl phenols. EU Member and 
candidate countries have to determine and reduce the environmental emissions of these priority substances to be able to reach good water status. In addition to these priority pollutants, specific hazardous substances determined by the countries based on the detailed evaluations of possible toxic effects and their presence in the surface water depending on the point and nonpoint discharges have to be monitored and if any of them are detected in the water, the protective actions have to be defined.

PAH concentrations in some of the surface waters of the EU countries have been monitored. It has been revealed that the total PAHs concentrations measured in different regions around the world may vary depending on PAHs' diversity according to urban runoff, industrial discharge or combustion sources [3]. The other factor is the analytical and instrumental method used for the determination of PAHs in the water. The directive specifies the performance criteria and methods required to ensure reliability in the measurement of pollutant concentrations of the member states in the studies to be carried out in the field of water analysis [4]. According to directive, priority substances concentration should not exceed the Ecological Quality Standard (EQS), specified in WFD to ensure a good chemical condition in surface waters [5]. EQS, which is tools for the protection of biodiversity in water bodies, is used to set discharge limit and classification of water body based on WFD.

In this work, PAHs, listed in Annex X-2013/39/EC and specific hazardous substances, listed in regulation of Surface Water Quality Management published by Ministry of Forest and Water Affairs in Turkey were monitored in Büyük Menderes River for a year. The detected PAH concentrations were evaluated according to EQS values.

\section{Materials and methods}

\subsection{Study area}

Büyük Menderes River rises on Turkey's southwest plateau and flows westward. The river basin has been expanded into a wide valley. The river, which is born in Afyon/Dinar region, turns south near Aydın region and reaches to the Aegean Sea after about $584 \mathrm{~km}$. Water is primarily used for agricultural irrigation purpose. There are intensive industrial activities in the Denizli region, which is located in the central area of the river basin. There were 45 sampling stations along the Büyük Menderes Basin (Figure 1). The samples were collected from 15 lake (BMG), 2 transition water, 4 coastal (BMGS) and 26 river (BMN) monitoring stations. Büyük Menderes River were classified as the 4 th class water according to organic substance concentration [6].

\subsection{Sampling and analysis}

Samples were collected monthly from September 2015 to August 2016 for 12 months. A total of two bottle surface water samples were taken from each sampling point by using $1 \mathrm{~L}$ precleaned amber bottles with PTFE screw caps for investigation of PAHs. Surface water samples were collected around $0.3 \mathrm{~m}$ below water surface and stored in the dark at $4{ }^{\circ} \mathrm{C}$ by addition of $\mathrm{Na}_{2} \mathrm{~S}_{2} \mathrm{O}_{3} .5 \mathrm{H}_{2} \mathrm{O}$. ISO 5667-6 standard method is used for sampling of pollutants and TS EN ISO 5667-3 standard is applied for the storage, transportation and storage of samples. Liquid-Liquid Extraction (US Environmental Protection Agency (1996) Method 3510C) was used for the PAH analysis.

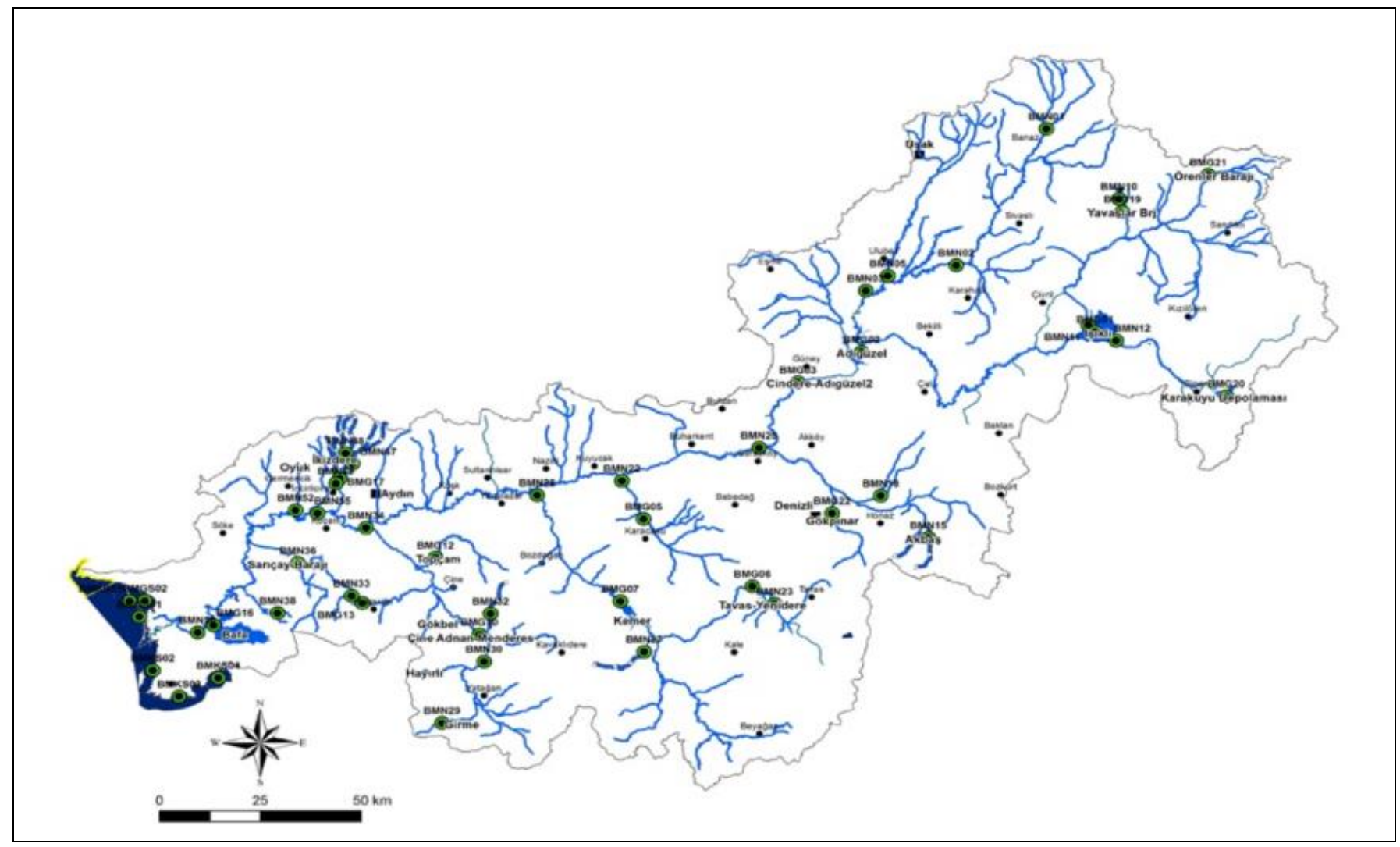

Figure 1: Monitoring stations in Büyük Menderes Basin. 
GC/MSMS (Agilent series 7000C-GC/MS Triple Quadrupole, $7890 \mathrm{~B}-\mathrm{GC}$ System), equipped with a $30 \mathrm{~m} \times 0.25 \mathrm{~mm} \times 0.25 \mu \mathrm{m} 5 \%$ Phenyl Methyl Siloxane Agilent J\&W HP-5 column was used for the determination of PAH concentration. The chromatographic run conditions were as follows: inlet temp, $60^{\circ} \mathrm{C}$; transfer line temp, $300{ }^{\circ} \mathrm{C}$; Oven temperatures, $60^{\circ} \mathrm{C}$ for $2 \mathrm{~min}, 25^{\circ} \mathrm{C} / \mathrm{min}$ to $300^{\circ} \mathrm{C}$, hold for $8.4 \mathrm{~min}$. Vent flow was $100 \mathrm{ml} / \mathrm{min}$ for $0.09 \mathrm{~min}$. Helium was used as the carrier gas at velocity of $30 \mathrm{~cm} / \mathrm{s}$ constant flow mode. Run time 20 min. Injected sample volume was $25 \mu \mathrm{L}$. MS conditions were as follows: Collision gas was nitrogen, constant flow with $1.5 \mathrm{ml} / \mathrm{min}$. Quench gas was helium, constant flow, $2.25 \mathrm{ml} / \mathrm{min}$. MS temp was $300{ }^{\circ} \mathrm{C}$ for source and $230{ }^{\circ} \mathrm{C}$ for quadrupoles.

\section{Results and discussion}

\subsection{Evaluation of PAH pollution based on MAC-EQS}

The monitoring study was conducted for 1 month. Anthracene, Benzo[a]pyrene, Benzo[b]fluoranthene, Benzo[ghi]perylene, Benzo[k]fluoranthene, Fluoranthene, Indeno [1,2,3-cd] pyrene, Naphthalene are the PAHs in the priority substances list of WFD. Additionally, 1-Methylnaphthalene, Acenaphthene, Acenaphthylene, Chrysene, Fluorene, Perylene, Phenanthrene, Pyrene were the PAHs monitored in the Büyük Menderes Basin. The PAHs with the concentration higher than Limit of Detection (LOD) value were reported in and evaluated in the study. The average concentration of PAH was compared with the MAC-EQS value of the corresponding PAH. The PAH concentration, which was higher than MAC-EQS value, was considered as the pollutant in the river.

Benzo[ghi]perylene is another PAH listed in the regulations. It could be found in plastic, petrochemical and metal industry discharges. The emission from incomplete burning of fossil fuels is the other contamination source. Benzo[ghi]perylene, has got 6 aromatic rings. Its solubility in the water is the lowest regarding to the other PAHs. In addition, its volatility is low too. Therefore, as benzo[ghi]perylene is somehow discharged to the surface water, there will be accumulation on the sediment. The MAC-EQS value of Benzo[ghi]perylene is $0.0082 \mathrm{ppb}$ and $0.00082 \mathrm{ppb}$ for rivers/lakes and for coastal/transitional waters, respectively. The highest concentrations were encountered in September 2015 with the concentration range of $0.0015 \mathrm{ppb}$ to $0.035 \mathrm{ppb}$. In October 2015, December 2015, April 2016 and July 2016, the concentrations in the whole monitoring stations were generally lower than $0.003 \mathrm{ppb}$ (Figure 2).

1-methylnaphthalene has been listed in the national specific pollutant list. It has two ring structure and it has the highest solubility in water. Although the physical properties of PAHs vary according to their molecular weight, each added ring reduces the solubility of $\mathrm{PAH}$ in water. Four or more ringed PAHs have low volatility. Low-weight PAHs are generally observed in the gas phase [7]. 1-methylnaphthalene sources are coal production, detergent production, textile industry and the use of wood protection chemicals. It is also emitted through incomplete combustion and pyrolysis of organic matter. Its half-life in surface water is $\mathbf{5 4}$ hours. It is also expected to evaporate from the soil and water surfaces. 1-methylnaphthalene tends to accumulate in aquatic organisms. MAC-EQS value is 29 ppb for rivers, lakes, coastal and transitional water. 1-methylnaphthalene was observed in the river basin during the monitoring period in September 2015, October 2015, May 2016 and July 2016 period. The maximum concentration with $2.08 \mathrm{ppb}$ was obtained in October 2015 in BMN11 station, which is located in the agricultural area. None of the detected concentrations of 1methylnaphthalene exceeded the MAC-EQS.

Anthracene is the priority pollutant with 0.4 ppb MAC-EQS value for surface waters. It has very low volatile property and, hence tends to accumulate in sediment or soil. Anthracene can be found in the wastewater of wood preservatives and paint production industries. It has high toxic effect on aquatic organisms. In the monitoring studies, the anthracene was commonly detected along the river basin. BMG03 station is a reservoir located between the forest and agricultural region. At this station, the highest anthracene concentration was measured as $0.028 \mathrm{ppb}$. This value is far below the MAC-EQS of $66 \mathrm{ppb}$. The frequency of detection along the river basin was lower in September 2015, December 2015 and May 2016.

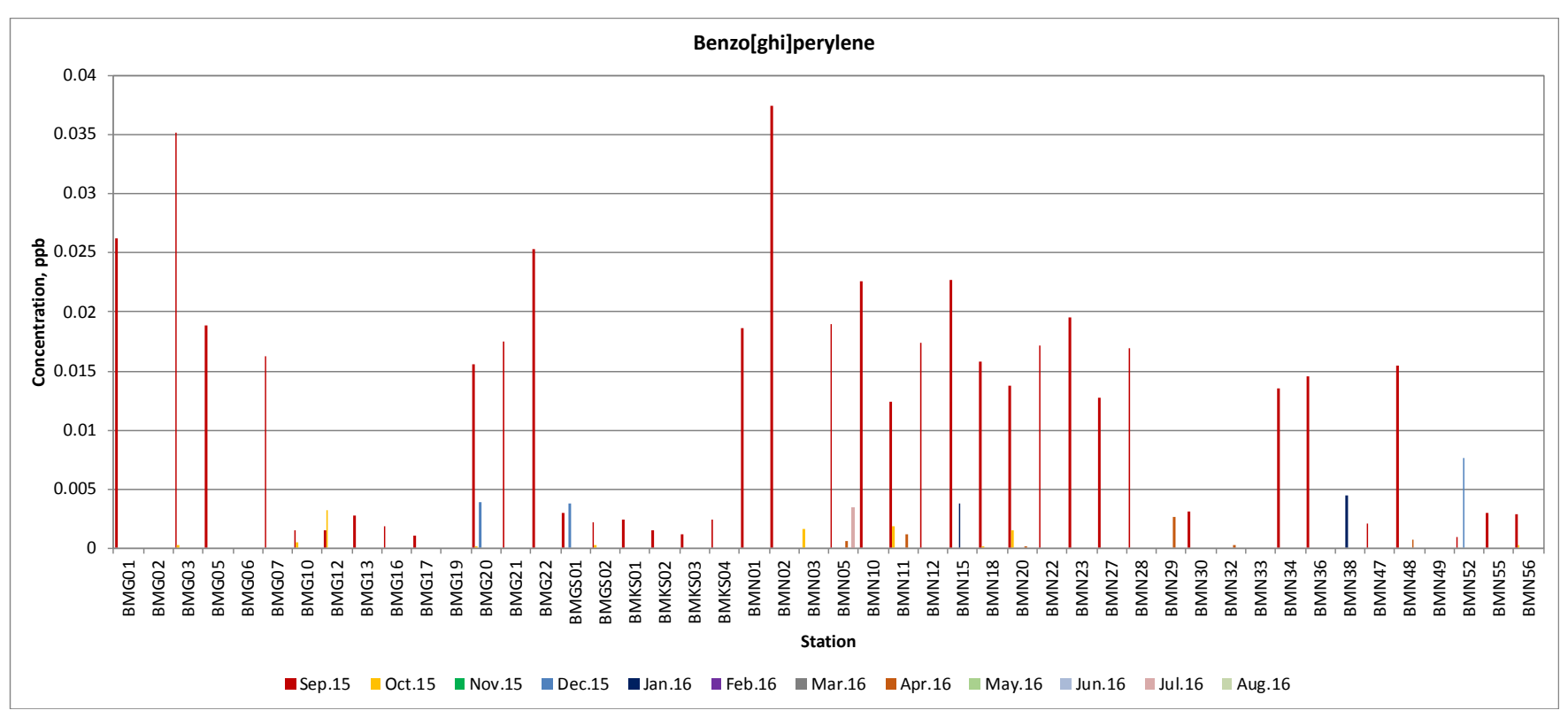

Figure 2: Variation of Benzo[ghi]perylene concentration for monitoring stations. 
Acenaphthylene is one of the specific pollutants and its MAC-EQS value is $66 \mathrm{ppb}$. Acenaphthylene is widely used in the production of electronic materials, plastics and paints. It is also observed in diesel exhaust emissions, wood and coal burning. It was commonly observed in the river basin despite slightly soluble in water. After mixing with water, acenaphthylene is adsorbed to sediment and suspended solids. Volatility half-life is 12 hours in river waters and 7.5 days in lakes. However, the estimated evaporation half-time can increase from days to months because of desorption process from sediment and soil. The maximum detected concentration in the Büyük Menderes River is $0.13 \mathrm{ppb}$, which is below the limit value.

Acenaphthene, which is a combustion product, may widely distributed to the environment. Furthermore, it could be emitted to the surface water through wastewater discharges from pharmaceutical, paint and plastic production processes or through the consumption of insecticide and fungicide for agricultural purposes, for example. It is readily biodegradable in water. Evaporation half-life is 11 days in river waters and 39 days in lakes. Acenaphthene was detected in river waters and lakes during monitoring periods of December 2015, February 2016, March 2016 and April 2016. The maximum concentration detected was $0.11 \mathrm{ppb}$ at BMN52 station, which is located in the agricultural area. However, the concentrations measured at all monitoring stations for acenaphthene are below the value of MAC-EQS (66 ppb).

Benzo[a]pyrene is priority pollutants. It is the most carcinogenic and mutagenic chemical among the PAHs. Therefore, it is used as a marker for PAH analysis in water. Benzo[a]pyrene with 5 rings has low solubility in water compared to other PAHs. It is extremely stable. It has lipophilic and nonpolar characteristics. Benzo[a]pyrene is present in exhaust gases of gasoline, diesel vehicles, pyrolysis products, coal tar, asphalt, wood smoke, coal combustion emissions, commercial solvents. Aromatic rings are extremely stable and very difficult to break. Therefore, it tends to accumulate in aquatic organisms. MAC-EQS value is $0.27 \mathrm{ppb}$ for rivers/lakes and $0.027 \mathrm{ppb}$ for coastal/transitional waters. Benzo[a]pyrene was one of the most commonly observed PAHs in the river basin during September 2015. The maximum level was observed as $0.013 \mathrm{ppb}$ in December 2015 in the transitional water stations named as BMGS01 and BMGS02. Although this is the highest level observed in the river, this concentration is considerably below the MAC-EQS value of the transition water.

Benzo[b]fluoranthene, which is listed in priority pollutants, has 5 rings and has low solubility in water. Its volatile property is also very low, and sediment accumulation is generally observed. Plastic, petrochemical and metal industries are the main source for Benzo[b]fluoranthene contamination. It has a carcinogenic effect due to high toxicity. The concentration of Benzo[b]fluoranthene was observed as 0.013 ppb in BMG03, which is a lake station and there are agricultural areas around it. Although the values observed are smaller than the MAC-EQS value of $0.017 \mathrm{ppb}$, the observed concentration is close to the quality standard value. Therefore, this $\mathrm{PAH}$ deserves special attention and should be considered as a risk factor for the contamination of surface water. The MAC-EQS of Benzo[k]fluoranthene, listed in priority pollutants, is $0.017 \mathrm{ppb}$ for rivers/lakes, coastal and transitional waters. Benzo[k]fluoranthene, which has low volatility and low solubility in water, is a substance formed by incomplete combustion. It is slowly degraded by microorganisms in the environment. This substance is detected in the tissues of aquatic animals such as fish. For the whole period of monitoring work carried out throughout the river basin, the concentrations of Benzo[k]fluoranthene reached $0.045 \mathrm{ppb}$ in BMN20 in September 2015 (Figure 3). This station is located in the agricultural area and there are industrial activities. Industrial discharges can be considered as point source for the observed concentrations. The other detected concentrations were below $0.005 \mathrm{ppb}$.

Phenanthrene, which is composed of 3 benzene rings, is insoluble in water. Its volatile property is low, and it generally tends to accumulate in the sediment. Phenanthrene is used as intermediates in the production of pesticides, explosive and dye. It is in the list of specific pollutants and the value of MACEQS is $11.2 \mathrm{ppb}$.

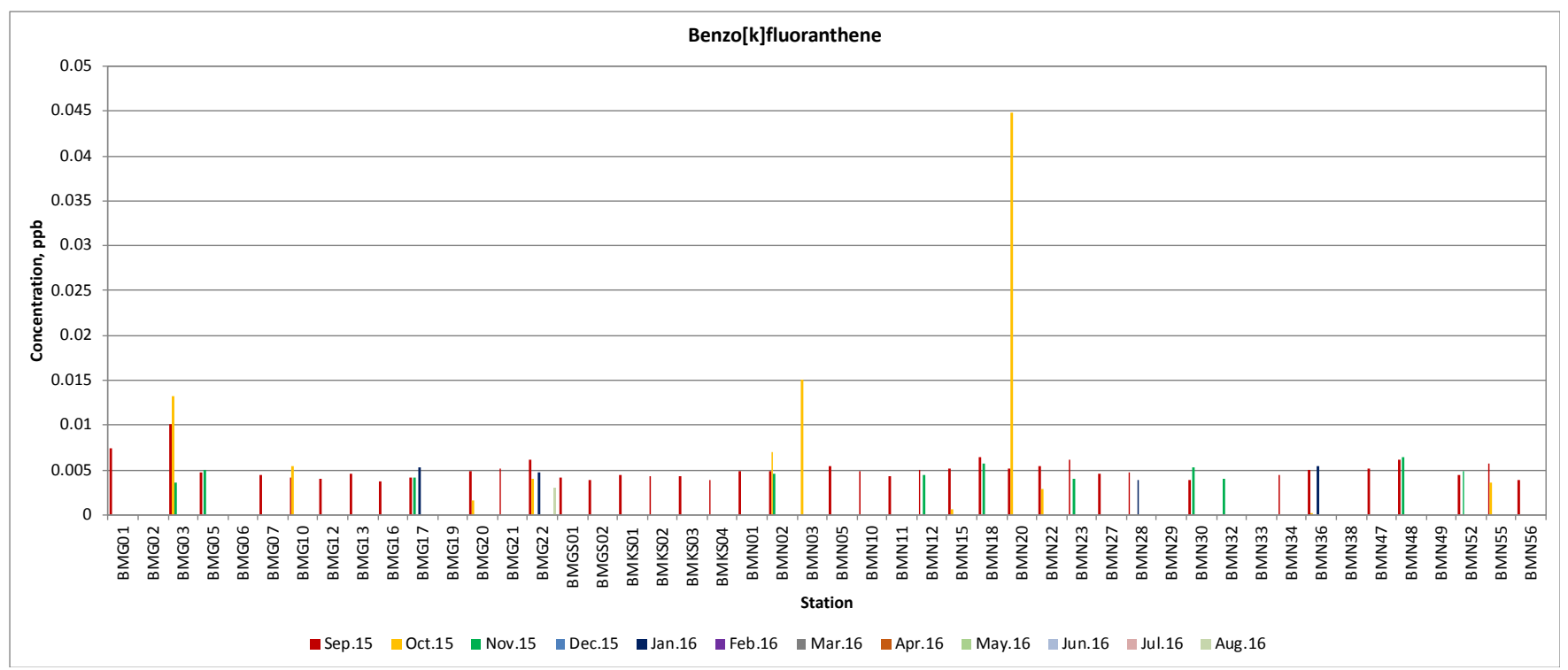

Figure 3: Variation of Benzo[k]fluoranthene concentration for monitoring stations. 
Phenanthrene was commonly observed in all station in September 2015 and October 2015. The detected concentrations in this period were less than $0.1 \mathrm{ppb}$. The maximum concentration was observed in a reservoir station namely BMG03 and it was about $0.25 \mathrm{ppb}$, which is again below the MAC-EQS value. Florentine is the raw material for the production of paints, pharmaceuticals and agricultural products. It is also found in coal, oil, automobile exhaust and emitted to the atmosphere as a result of incomplete combustion. Fluoranthene is listed in possible human carcinogenic substances due to its strong toxic properties. Therefore, Fluoranthene is in the list of priority pollutants. The MAC-EQS value of this substance is $0.12 \mathrm{ppb}$. This PAH was detected rarely along the river in September 2016 and March 2016 and June 2016 (Figure 4). Fluorene, which is a specific pollutant, was widely observed in especially September 2015 and in November 2015. Mostly, the measured concentrations remained below $0.4 \mathrm{ppb}$. The maximum observed concentration was $0.09 \mathrm{ppb}$ which is below the MAC-EQS of 47 ppb. Indeno [1,2,3-cd] pyrene has low water-solubility with its 6 -ring structure. The volatility property of indeno [1,2,3-cd] pyrene is also very low, and it tends to accumulate on the sediment. Petrochemical, plastics and metal industries are one of the point sources for indeno [1,2,3-cd] pyrene. It is also found in coal, coal tar, exhaust from burnt coal, used motor and automobile exhaust. It is toxic to aquatic life and accepted as possible carcinogenic substance for humans. The highest concentration was observed as $0.12 \mathrm{ppb}$ in the lake water. Although it was commonly found in September 2015, the concentrations were usually less than $0.01 \mathrm{ppb}$ in the river basin.

Chrysene that consists of four benzene rings is a priority pollutant associated with naphthalene and anthracene in coal tar. It is formed during incomplete combustion of oil, wood, coal. It can be found in wastewater of petrochemical, metal, plastic, paint industries. The biodegradability of chrysene by organisms is slow. In addition, there is a tendency to accumulate within aquatic organisms such as fish. MAC-EQS value is $19 \mathrm{ppb}$ for all water body. In particular, in March 2016, chrysene was measured at all stations. However, these concentrations were generally less than $0.05 \mathrm{ppb}$. Naphthalene is available in natural resources such as oil and coal. It is used for the production of polyvinyl chloride plastics. Its structure contains a pair of benzene rings. It is possible to evaporate naphthalene from water and soil surfaces. Bacteria can degrade naphthalene, mostly. Therefore, no accumulation in aquatic life is expected. MAC-EQS value is $130 \mathrm{ppb}$ and the concentration in exceeds this value was not observed in the river basin. It was detected more frequently in September 2015- December 2015. Perylene, made up of five benzene rings, is a PAH listed in specific pollutants. Perylene is released into the atmosphere as a result of incomplete combustion of coal, oil, etc., like the other PAHs. It is not expected to evaporate into the air from the soil and water surfaces. Due to the low biodegradability, the accumulation within the living organisms should be expected. During the monitoring period, only $0.0045 \mathrm{ppb}$ and 0.00158 ppb concentrations were observed in November 2015 and February 2016 and it did not exceed the value of MAC-EQS. Pyrene consists of four benzene rings and is listed in priority pollutants. It is used in the production of other chemicals and dyes. It is also found in emissions of incomplete burning of oil, coal, wood. Pyrene released into the atmosphere is eventually transported to the soil and aquatic environment by dry deposition. It tends to accumulate in the sediment. It was widely observed in September 2015 and December 2015 along the river basin although slightly soluble in water. The maximum observed concentration was $0.36 \mathrm{ppb}$ which is detected in BMG02. The detected value is very close to the MAKEQS (0.4ppb) (Figure 5). Therefore, it can be said that Pyrene is a PAH that carries risks for the river basin.

\subsection{Evaluation of PAH pollution based on AA-EQS}

The annual average of PAH concentrations, obtained in the monitoring period, were compared with the AA-EQS. The results indicated that the only PAH which exceeds the AA-EQS value is fluoranthene. Figure 6 shows the variation of fluoranthene concentration for monitoring stations. Fluoranthene concentrations were measured above AA-EQS in many stations. The highest value for fluoranthene was found as $0.002 \mathrm{ppb}$.

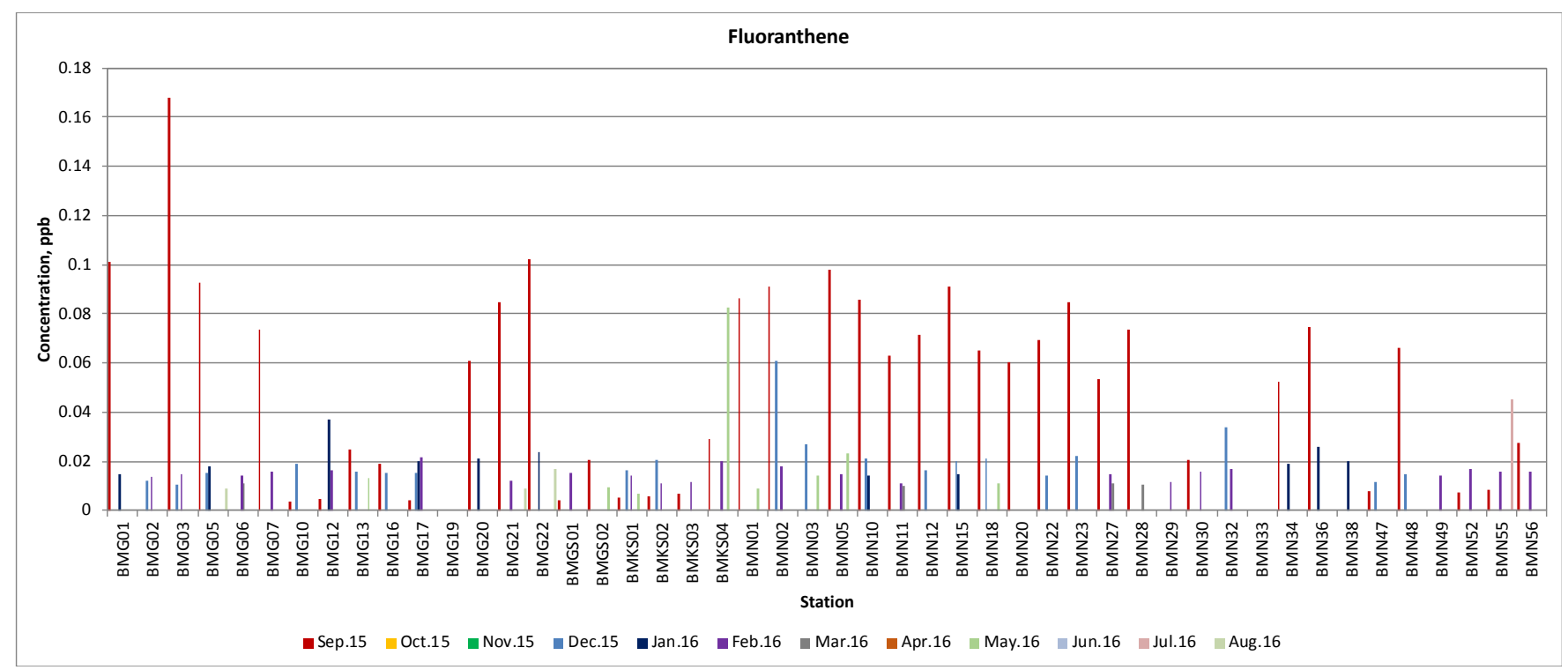

Figure 4: Variation of Fluoranthene concentration for monitoring stations. 


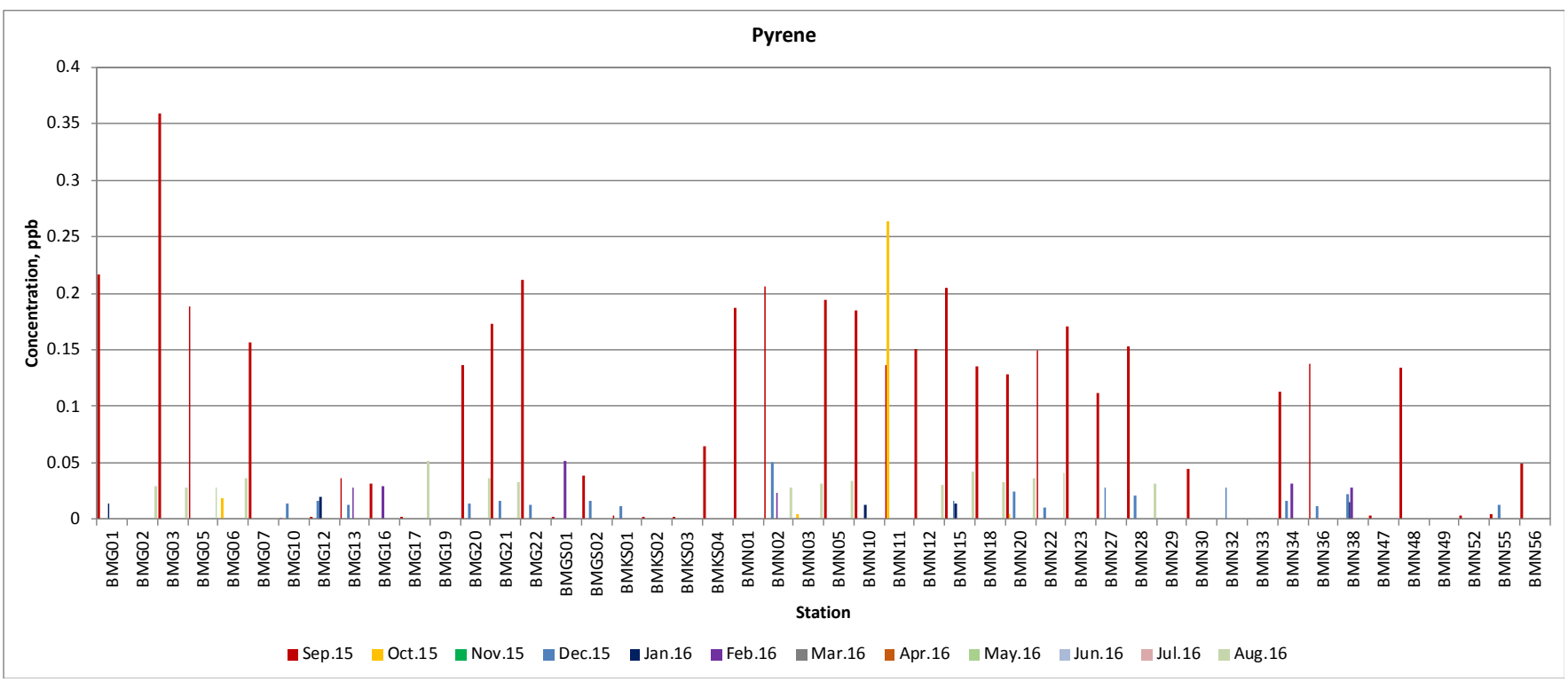

Figure 5: Variation of Pyrene concentration for monitoring stations.

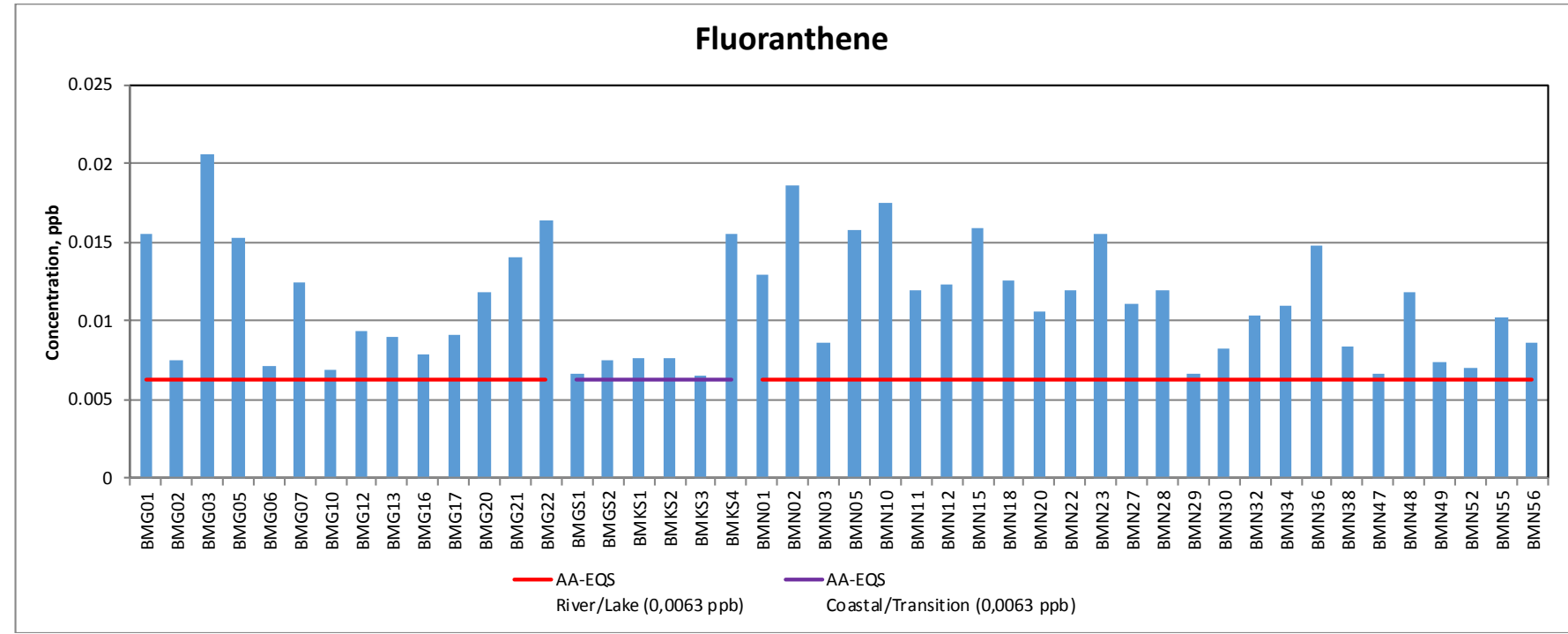

Figure 6: Annual average concentration of Fluoranthene.

Water quality classification was conducted for priority and specific pollutants according to WFD. The directive states that if the observed annual average concentration of a chemical in the priority pollutants list is below the value of AA-EQS, the water is classified as "Good". But if the concentration is above the AA-EQS, then the chemical status of water is classified as "Moderate". The results if this monitoring study showed that, fluoranthene concentration exceeds the AA-EQS concentration in Büyük Menders River. That result makes the chemical status of the Büyük Menders River is "Moderate".

\section{Conclusions}

Surface water quality monitoring studies for the micropollutants listed in EU Directives and in the national regulations of the countries initiated the awareness about the protection of the natural water resources against to pollution by point and nonpoint sources. The next step is to take actions in order to improve water quality level and to bring all-natural waters to "good status" in terms of chemical, biological and hydromorphological ones. The type and the detected concentrations of the chemicals are critical in determining the actions that will be taken. The protective actions may include revision of existing wastewater treatment processes, building new ones for the point sources and more strict regulations for nonpoint sources like replacement of toxic pesticides with the natural ones. Büyük Menders River was monitored based on the EU WFD. The results indicated that there is PAH pollution, but it is not strong. Since the concentrations of most of PAH were below the MAC-EQS and AA-EQS and no persistence above existence of PAHs were observed. PAHs that pose major risks in the river are benzo[k]fluoranthene, benzo[ghi]perylene, pyrene and fluoranthene. Special attention should be given to fluoranthene which was detected above the annual average value in both coastal waters and lakes/rivers. In addition, point or nonpoint sources of pyrene should be evaluated to eliminate the pyrene pollution risk. Finally, discharge standards for point sources and preventive actions for nonpoint sources should be developed to ensure good chemical status in Büyük Menderes River basin. 


\section{Acknowledgments}

This work was supported by the Scientific and Technical Research Council of Turkey (TUBITAK) under Grant No. $112 \mathrm{G} 083$.

\section{References}

[1] Kim K-H, Jahan S, Kabir E, Brown RJC. "A review of airborne polycyclic aromatic hydrocarbons (PAHs) and their human health effects". Environment International, 60, 71-80, 2013.

[2] Countway RE, Dickhut RM, Canuel EA. "Polycyclic aromatic hydrocarbon (PAH) distributions and associations with organic matter in surface waters of the York River, VA Estuary". Organic Geochemistry, 34(2), 209-224, 2003.

[3] Nagy P, Fekete J, Sharma VK. "Polycyclic aromatic hydrocarbons (PAHs) in surface waters of RáckeveiSoroksári Danube Branch, Hungary". Journal of Environmental Science and Health, Part A, 42(3), 231-240, 2007.
[4] Díaz-González M, Gutiérrez-Capitán M, Niu P, Baldi A, Jiménez-Jorquera $\quad \mathrm{C}, \quad$ Fernández-Sánchez $\quad \mathrm{C}$ "Electrochemical devices for the detection of priority pollutants listed in the EU water framework directive". TrAC Trends in Analytical Chemistry, 77, 186-202, 2016.

[5] Mancini L. Fidente RM. "The Water Framework Directive 2000/60/EU: State of the Art of the European Legislation". Reports ISTISAN - National Institute of Health, 2007.

[6] Turan F, Ulku G. "Monitoring water quality parameters and pollution discharge loads of Gökpinar and Çürüksu Creeks, Denizli, Turkey" Pamukkale University Journal of Engineering Sciences, 19(3), 133-144, 2013.

[7] Kameda T. "Atmospheric chemistry of polycyclic aromatic hydrocarbons and related compounds". Journal of Health Science, 57(6), 504-511, 2011. 